\title{
Peran Hukum Dalam Pembangunan Ekonomi Indonesia: Arah Kebijakan Pemerintah Menghadapi Praktik Dumping
}

\author{
Fahmi Fairuzzaman \\ Fakultas Hukum Universitas Muhammadiyah Surakarta Jawa Tengah, Indonesia \\ Jln. Ahmad Yani, Pabelan, Kartasura, Surakarta 57162, Jawa Tengah, Indonesia \\ fahmi.fairuzzaman@ums.ac.id
}

\begin{abstract}
This research raises issues, firstly, the direction of policies implemented by the Government of Indonesia to deal with dumping practices carried out by other countries against Indonesia. Secondly, the role of law in economic development in Indonesia related to preventing fraudulent dumping practices. The method used is normative legal research. The results of the study conclude that first, the policy directed by the Government of Indonesia in dealing with the fraudulent practice of dumping by other countries against Indonesia is carried out by ratifying the Agreement for the Establishment of the World Trade Organization (WTO). With this ratification, Indonesia must then adjust its policies in international trade to comply with WTO provisions, including implementing anti-dumping policies in accordance with the Anti-Dumping Agreement. Second, the law acts as a tool for carrying out economic development. The law acts as a tool to prevent dumping practices in order to support the implementation of economic development in Indonesia.
\end{abstract}

Key Words: Dumping; law and economic development

\begin{abstract}
Abstrak
Penelitian ini mengangkat permasalahan, pertama, arah kebijakan yang diberlakukan Pemerintah Indonesia untuk menghadapi praktek dumping yang dilakukan oleh negara lain terhadap Indonesia. Kedua, peran hukum dalam pembangunan ekonomi di Indonesia terkait dengan pencegahan praktek curang dumping. Metode yang digunakan adalah penelitian hukum normatif. Hasil penelitian menyimpulkan, pertama, arah kebijakan yang diberlakukan Pemerintah Indonesia dalam menghadapi praktek curang dumping oleh negara lain terhadap Indonesia dilakukan dengan meratifikasi Perjanjian Pembentukan Organisasi Perdagangan Dunia (WTO). Dengan ratifikasi tersebut Indonesia kemudian harus menyesuaikan kebijakannya dalam perdagangan internasional agar sesuai ketentuan WTO, termasuk menerapkan kebijakan anti-dumping sesuai dengan Anti-Dumping Agreement. Kedua, hukum berperan sebagai alat untuk melaksanakan pembangunan ekonomi. Hukum berperan sebagai alat untuk mencegah praktek dumping guna mendukung terlaksananya pembangunan ekonomi di Indonesia.
\end{abstract}

Kata-kata Kunci: Dumping; hukum dan pembangunan ekonomi 


\section{Pendahuluan}

Setiap negara yang ada, terutama negara-negara berkembang, akan melakukan pembangunan agar dapat membuat warganya sejahtera. Salah satu upaya yang dapat dilakukan untuk mendukung pembangunan ekonomi suatu negara adalah dengan melakukan kegiatan perdagangan internasional. Maksud dari perdagangan internasional disini adalah suatu aktivitas dagang yang melintasi batas-batas negara. Semua negara yang ada di dunia ini, dapat dikatakan tidak bisa hanya bergantung pada sumber daya yang dimilikinya sendiri, bahkan negara seperti Korea Utara yang sangat tertutup akan dunia luar juga tetap masih melakukan hubungan dagang dengan beberapa negara lain, meskipun tidak masif seperti yang dilakukan oleh para negara anggota WTO (World Trade Organization). Oleh karena itu, perdagangan internasional sangat diperlukan untuk dapat memenuhi kebutuhan-kebutuhan dalam negeri tersebut. Selain daripada untuk pemenuhan kebutuhan dalam negeri tersebut, perdagangan internasional dapat juga bermanfaat untuk meraih keuntungan. Cara yang dapat digunakan diantaranya adalah dengan memasarkan produk dalam negeri ke negara-negara lain atau dengan kata lain mengekspor produk dalam negeri. Hal tersebut tentunya juga mendukung pembangunan ekonomi suatu negara tidak terkecuali Indonesia. Dengan semakin baiknya pembangunan ekonomi suatu negara, maka tentu saja dapat semakin meningkatkan kesejahteraan warganya. Oleh karena itu, penting bagi Indonesia untuk menaruh perhatian pada bidang perdagangan internasional ini dalam rangka mendukung pembangunan ekonomi dalam negeri.

Berbicara mengenai perdagangan yang melintasi batas negara, tentu saja didalamnya terlibat banyak pihak seperti diantaranya negara-negara tempat terjadinya aktivitas perdagangan internasional, ataupun para pelaku usaha yang menjalankan aktivitas perdagangan internasional tersebut. Dengan terlibatnya berbagai pihak dalam aktivitas tersebut, maka timbul juga kepentingankepentingan para pihak yang menyertainya. Agar kepentingan-kepentingan tersebut tidak saling bertabrakan atau tumpeng tindih dan tetap dapat terjaga, maka tentu saja diperlukan suatu aturan hukum yang dapat menjadi instrumen penjaga kepentingan-kepentingan tersebut tanpa merugikan pihak-pihak tertentu yang terlibat di dalamnya. Instrumen hukum yang dimaksud adalah hukum internasional. Pada praktiknya, perdagangan internasional dilakukan antara perusahaan-perusahaan ataupun individu-individu yang berada di dalam negaranegara yang menjadi tujuan ekspor-impor. Akan tetapi, dalam hal pembentukan aturan-aturan hukum terkait perdagangan internasional tersebut dan juga yang terikat dengan hukum internasional adalah suatu negara. Oleh karena itu, dalam 
hukum internasional, negara adalah yang mempunyai tanggung jawab, dan bukan perusahaan ataupun individu secara langsung. ${ }^{1}$

Indonesia merupakan salah satu contoh negara yang juga aktif melakukan aktivitas perdagangan internasional. Hal tersebut dapat dilihat dari perjanjianperjanjian internasional yang melibatkan Indonesia. Salah satu contoh perjanjian internasional di bidang perdagangan internasional yang melibatkan Indonesia adalah Agreement Establishing the World Trade Organization (WTO) atau dikenal juga dengan Perjanjian Pembentukan Organisasi Perdagangan Dunia. Agreement tersebut kemudian diratifikasi ke dalam Undang-Undang Republik Indonesia Nomor 7 Tahun 1994 tentang Pengesahan Agreement Establishing the World Trade Organization (Persetujuan Pembentukan Organisasi Perdagangan Dunia). Dengan menjadi salah satu pihak dalam perjanjian tersebut dan juga telah meratifikasinya, maka Indonesia juga menjadi anggota dari WTO (World Trade Organization) dan dengan demikian juga harus mengikuti peraturan-peraturan yang disepakati di dalamnya.

Pada prinsipnya, WTO menerapkan suatu sistem perdagangan bagi para negara anggotanya. Sistem itu biasa disebut dengan sistem perdagangan bebas atau free trade. Sistem perdagangan bebas tersebut adalah cara untuk pengurangan besar-besaran tarif dan hambatan lain dalam perdagangan, serta penghapusan perlakuan diskriminatif dalam hubungan perdagangan internasional. ${ }^{2}$ Pada hakikatnya, WTO menginginkan berkurangnya hambatanhambatan tersebut, baik hambatan tarif maupun non-tarif, agar dalam lalu lintas perdangangan internasional dapat tercipta persaingan yang adil antara negaranegara yang terlibat dalam aktivitas perdagangan tersebut.

Bersamaan dengan perdagangan yang bebas hambatan, timbul persaingan yang ketat antara para pelaku ekonomi dalam kegiatan perdagangan internasional. Persaingan ketat tersebut ternyata juga memiliki sisi negatif, yaitu lahirnya praktik-praktik curang dalam perdagangan atau disebut juga dengan unfair trade. Salah satu contoh praktek tersebut adalah dumping yang dilakukan oleh suatu negara terhadap negara lainnya. Dumping termasuk dalam praktek curang karena dapat merugikan industri dalam negeri dari negara yang terkena dumping. Praktek curang tersebut tentu saja dapat berpengaruh buruk bagi pembangunan ekonomi suatu negara. Oleh karena itu, praktek curang dumping harus dicegah agar industri dalam negeri dapat terlindungi dan tercipta suatu

1 Muh. Risnain, "Politik Hukum Perlindungan Industri dalam Negeri Indonesia dalam Menghadapi Perdagangan Bebas", Fiat Justisia Jurnal Ilmu Hukum, Vol. 5, No. 3, September - Desember 2011, hlm. 277.

2 M. Ya'kub Aiyub Kadir, "The World Trade Organization (WTO) Free Trade within Fair Trade Challenges", Mimbar Hukum, Vol., 26 No. 1, Februari 2014, hlm. 127. 
praktek perdagangan yang sehat sehingga pembangunan ekonomi dapat berjalan dengan baik.

Demi mewujudkan hal tersebut di atas, maka perlu diketahui terlebih dahulu bagaimanakah arah kebijakan pemerintah untuk menghadapi praktikpraktik curang tersebut khususnya dumping. Arah kebijakan tersebut kemudian tentu saja perlu diwujudkan ke dalam suatu aturan hukum yang dapat menjadi instrumen pencegahan praktik curang dalam perdagangan internasional sehingga dapat mewujudkan pembangunan ekonomi yang baik. Dengan demikian, hukum memegang peranan penting dalam pembangunan ekonomi di Indonesia.

\section{Rumusan Masalah}

Berdasarkan uraian tersebut, permasalahan akan dibatasi sebagai berikut: pertama, bagaimanakah arah kebijakan yang diberlakukan Pemerintah Indonesia untuk menghadapi praktek dumping yang dilakukan oleh negara lain terhadap Indonesia? Kedua, bagaimanakah peran hukum dalam pembangunan ekonomi di Indonesia terkait dengan pencegahan praktek curang dumping?

\section{Tujuan Penelitian}

Tujuan dari penelitian ini adalah untuk: pertama, mengetahui serta memahami arah kebijakan yang diberlakukan Pemerintah Indonesia untuk menghadapi praktek dumping yang dilakukan oleh negara lain terhadap Indonesia; Kedua, mengetahui serta memahami peran hukum dalam pembangunan ekonomi di Indonesia terkait dengan pencegahan praktek curang dumping.

\section{Metode Penelitian}

Artikel penelitian ini menggunakan metode penelitian hukum normatif. Fokus utama dari penelitian hukum normatif ini adalah pada konsepsi hukum sebagai norma yang didalamnya mencakup nilai-nilai, hukum positif dan juga putusan pengadilan. Selain itu juga lebih difokuskan kepada pengkajian terhadap penerapan kaidah-kaidah atau norma-norma dalam hukum positif. ${ }^{3}$ Penelitian ini menggunakan data-data yang termasuk ke dalam data sekunder. Data sekunder tersebut terdiri dari bahan hukum primer maupun sekunder. Bahan-bahan Hukum tersebut kemudian dikumpulkan dengan metode Studi Kepustakaan. Setelah itu, data yang didapatkan tersebut akan diolah dan disajikan dengan cara deskriptif. Maksud dari deskriptif disini adalah dengan cara menggambarkan suatu pokok permasalahan yang dibahas secara menyeluruh dalam penelitian ini.

3 Johnny Ibrahim, Teori dan Metodologi Penelitian Hukum Normatif, Bayumedia Publishing, Malang, 2008, hlm. 295. 


\section{Hasil Penelitian dan Pembahasan}

\section{Praktek Curang dalam Perdagangan Internasional}

Perdagangan bebas mendorong terjadinya persaingan yang kompetitif dan ketat antara pelaku ekonomi yang terlibat di dalamnya. Persaingan tersebut tidak selalu memberikan dampak positif, tetapi juga memberikan dampak negatif. Maksud dari dampak negatif itu adalah terjadinya praktek curang dalam proses perdagangan internasional. Praktik curang disebabkan oleh keinginan dan tuntutan dari para pelaku ekonomi di dalamnya untuk terus bersaing meraih keuntungan sebesar mungkin. Hal tersebut tentu akan menjadi penghambat dalam perdagangan internasional. Adanya kondisi tersebut kemudian dapat menyebabkan persaingan menjadi tidak sehat. Salah satu contoh tindakan yang termasuk ke dalam praktik curang adalah dumping.

Dumping, menurut Black Law Dictionary, didefinisikan sebagai suatu tindakan menjual barang dalam jumlah yang besar, dengan harga yang kurang dari nilai wajar atau nilai normal, atau dapat diartikan juga sebagai menjual barang ke luar negeri dengan harga di bawah harga pasar dalam negeri. ${ }^{4}$ Selanjutnya, menurut Article II section (1) dalam Anti-Dumping Agreement, dumping didefinisikan sebagai suatu tindakan menjual sebuah barang ke pasar negara lain dengan harga yang lebih murah daripada "Nilai Normal" barang tersebut. ${ }^{5}$ Berdasarkan pengertian-pengertian tersebut dapat dilihat bahwa dumping dapat merugikan industri dalam negeri suatu negara pengimpor. Timbulnya kerugian salah satu pihak tersebut tentu bertentangan dengan tujuan dari adanya perdagangan bebas, yaitu persaingan yang adil diantara para pelaku ekonomi didalamnya. Selain itu praktek dumping juga dapat berdampak buruk bagi pembangunan ekonomi karena dengan meruginya industri dalam negeri suatu negara, maka perekonomian nasional juga ikut terganggu. Jika perekonomian nasional sudah terganggu, pembangunan yang sedang dilakukan pemerintah tidak akan berjalan dengan baik. Oleh karena itu, dumping harus dicegah agar tidak menimbulkan kerugian yang lebih luas lagi.

\section{Arah Kebijakan Hukum Ekonomi Nasional}

Pada pokoknya, ketika mengadakan suatu kegiatan mengkaji hukum ekonomi, maka arahnya adalah untuk meningkatkan daya dukung hukum atau peraturan perundang-undangan dalam suatu negara terhadap kegiatan ekonomi. Apabila suatu negara memiliki peraturan perundang-undangan yang lengkap

${ }^{4}$ Bryan A Garner, Black Law Dictionary, dalam Muh. Risnain, Op. Cit., hlm 284.

5 Peter van den Bossche, Daniar Natakusumah dan Joseph Wira Koesnaidi., Pengantar Hukum WTO (World Trade Organization), Cetakan Pertama, Yayasan Obor Indonesia, Jakarta, 2010, hlm. 39. 
dalam bidang ekonomi, maka hal tersebut akan menjamin adanya kepastian hukum bagi pelaksanaan hubungan hukum yang menciptakan hak dan kewajiban bagi para subjek hukum pada umumnya, serta dalam hubungan kegiatan ekonomi pada khususnya. ${ }^{6}$ Oleh karena itu, diperlukan suatu aturan dasar yang dapat memiliki daya cakup secara luas terutama dalam hal ini di bidang ekonomi untuk dijadikan landasan dalam arah kebijakan suatu negara. Indonesia memiliki aturan dasar berupa Undang-Undang Dasar Negara Republik Indonesia 1945 (UUD 1945) yang di dalamnya mengatur mengenai landasan kebijakan di bidang ekonomi. Hal tersebut terdapat dalam Bab XIV UUD 1945 mengenai Perekonomian Nasional dan Kesejahteraan Sosial yang secara spesifik diatur dalam Pasal 33 ayat (1) sampai (5). Pasal 33 tersebut mengatur sebagai berikut:

1. Perekonomian disusun sebagai usaha bersama berdasar atas asas kekeluargaan.

2. Cabang-cabang produksi yang penting bagi negara dan yang menguasai hajat hidup orang banyak dikuasai oleh negara.

3. Bumi dan air dan kekayaan alam yang terkandung di dalamnya dikuasai oleh negara dan dipergunakan untuk sebesar-besar kemakmuran rakyat.

4. Perekonomian nasional diselenggarakan berdasar atas demokrasi ekonomi dengan prinsip kebersamaan, efisiensi berkeadilan, berkelanjutan, berwawasan lingkungan, kemandirian, serta dengan menjaga keseimbangan kemajuan dan kesatuan ekonomi nasional.

5. Ketentuan lebih lanjut mengenai pelaksanaan pasal ini diatur dalam undang-undang.

Merujuk kepada pasal di atas, dapat dilihat bahwa frasa "Perekonomian disusun..." yang terdapat dalam Pasal 33 ayat (1) mengandung pengertian imperatif. Maksud dari imperatif disini adalah bahwa perekonomian nasional tidak begitu saja dibiarkan berjalan sendiri atau mengikuti kekuatan-kekuatan yang ada seperti contohnya kekuatan pasar bebas. Kata "disusun" dalam ayat tersebut menunjukkan adanya upaya pembangunan secara struktural perekonomian nasional melalui tindakan yang nyata. Tugas untuk menyusun bangunan ekonomi nasional tersebut merupakan kewajiban dari negara. ${ }^{7}$ Perlu adanya keterlibatan pemerintah dengan cara dibentuknya suatu pengaturan lanjutan mengenai arah perekonomian nasional. Pengaturan tersebut dapat dituangkan dalam bentuk Undang-Undang sebagaimana juga ditentukan dalam

${ }^{6}$ Sumantoro, Hukum Ekonomi, dalam Mardalena Hanifah, “Arah Kebijakan Hukum Politik Ekonomi”, Jurnal Ilmu Hukum, Vol. 3, No. 1, (Tanpa Tahun), hlm. 2.

7 Sri-Edi Swasono, Demokrasi Ekonomi: Keterkaitan usaha partisipatif Vs. Konsentrasi Ekonomi, dalam Muh. Risnain, Op. Cit., hlm. 285. 
Pasal 33 ayat (5) UUD 1945 agar perekonomian nasional dapat tersusun dengan baik.

Pasal tersebut juga mengatur mengenai penyelenggaraan perekonomian nasional yang didasarkan pada "demokrasi ekonomi" sebagaimana tercantum dalam Pasal 33 ayat (4) UUD 1945. Ayat tersebut merupakan ketentuan tambahan pasca bergulirnya reformasi untuk memperkuat bangunan ekonomi nasional. Selain itu juga ditegaskan didalamnya bahwa "demokrasi ekonomi" dijalankan dengan prinsip-prinsip kebersamaan, efisiensi, berkeadilan, berkelanjutan, berwawasan lingkungan, kemandirian, serta dengan menjaga keseimbangan kemajuan dan kesatuan ekonomi. ${ }^{8}$ Berdasarkan hal-hal tersebut diatas terlihat secara jelas bahwa arah kebijakan ekonomi nasional di Indonesia dilandaskan pada prinsip-prinsip demokrasi ekonomi yang mengandung ekonomi berkeadilan. Kemudian untuk menyusun dan melaksanakan perekonomian nasional sesuai dengan ketentuan dalam UUD 1945 tersebut, perlu dibentuk suatu peraturan mengenai arah kebijakan Indonesia yang kemudian diwujudkan dalam bentuk RPJP (Rencana Pembangunan Jangka Panjang).

\section{Rencana Pembangunan Jangka Panjang (RPJP) 2005-2025}

Rencana Pembangunan Jangka Panjang (RPJP) dituangkan ke dalam Undang-Undang Nomor 17 Tahun 2007 tentang Rencana Pembangunan Jangka Panjang Nasional Tahun 2005-2025. RPJP dapat menunjukkan kemana arah kebijakan Pemerintah Indonesia dalam rangka membangun negara. Dalam konteks kebijakan hukum, RPJP menjabarkan salah satu misi Indonesia yaitu reformasi hukum dan birokrasi. Pada bab IV.1.2 tentang mewujudkan bangsa yang berdaya-saing, bagian reformasi hukum dan birokrasi tersebut disebutkan dalam poin ke 34 dan 35. Misi reformasi hukum dan birokrasi itu dijabarkan dalam kedua poin tersebut sebagai berikut: pertama, Pembangunan hukum diarahkan untuk mendukung terwujudnya pertumbuhan ekonomi yang berkelanjutan; mengatur permasalahan yang berkaitan dengan ekonomi, terutama dunia usaha dan dunia industri; serta menciptakan kepastian investasi, terutama penegakan dan perlindungan hukum. Pembangunan hukum juga diarahkan untuk menghilangkan kemungkinan terjadinya tindak pidana korupsi serta mampu menangani dan menyelesaikan secara tuntas permasalahan yang terkait kolusi, korupsi, nepotisme (KKN). Pembangunan hukum dilaksanakan melalui pembaruan materi hukum dengan tetap memerhatikan kemajemukan tatanan hukum yang berlaku dan pengaruh globalisasi sebagai upaya untuk

8 Jimly Asshidiqie, Konsolidasi Naskah UUD 1945 setelah Perubahan Keempat, dalam Muh. Risnain, Op. Cit, hlm. 286. 
meningkatkan kepastian dan perlindungan hukum, penegakan hukum dan hakhak asasi manusia (HAM), kesadaran hukum, serta pelayanan hukum yang berintikan keadilan dan kebenaran, ketertiban dan kesejahteraan dalam rangka penyelenggaraan negara yang makin tertib, teratur, lancar, serta berdaya saing global. Kedua, Pembangunan aparatur negara dilakukan melalui reformasi birokrasi untuk meningkatkan profesionalisme aparatur negara dan untuk mewujudkan tata pemerintahan yang baik, di pusat maupun di daerah agar mampu mendukung keberhasilan pembangunan di bidang-bidang lainnya.

Kedua poin di atas, terutama pada poin pertama, jika diamati menunjukkan adanya hubungan antara pembangunan hukum dan pembangunan ekonomi. Dapat terlihat bahwa kebijakan hukum nasional diarahkan salah satunya untuk mendukung terwujudnya pertumbuhan ekonomi yang berkelanjutan. Selain itu, kebijakan tersebut juga diarahkan untuk mengatur permasalahan yang berkaitan dengan ekonomi dan terutama penegakan serta perlindungan hukum. Kebijakankebijakan itu dilaksanakan melalui pembaruan materi hukum dengan tetap memperhatikan majemuknya tatanan hukum yang berlaku serta adanya pengaruh dari globalisasi. Hal tersebut dilakukan sebagai suatu usaha yang bertujuan agar meningkatkan perlindungan serta kepastian hukum, penegakan hukum serta HAM (hak asasi manusia), kesadaran hukum. Selain itu, juga bertujuan untuk meningkatkan pelayanan hukum yang berlandaskan pada keadilan serta kebenaran, ketertiban, dan kesejahteraan dalam rangka penyelenggaraan negara yang semakin tertib, teratur, lancar, serta berdaya saing global.

Pembangunan ekonomi dapat terlaksana dengan baik tergantung pada pembangunan hukum nasional. Dalam rangka mewujudkan hal tersebut perlu dibentuk peraturan lebih lanjut untuk mendukung pembangunan ekonomi di Indonesia. Selain itu juga diperlukan peraturan untuk mengatasi permasalahanpermasalahan yang menghambat pembangunan ekonomi nasional. Hal tersebut menjadi penting sebab jika pembangunan ekonomi nasional terhambat maka pertumbuhan ekonomi yang berkelanjutan tidak dapat terwujud.

Perkembangan dunia perekonomian yang begitu pesat mengarahkan perekonomian kita, dalam konteks perdagangan, kepada era globalisasi dan liberalisasi. Dengan masuknya Indonesia ke dalam era liberalisasi perdagangan, maka perlu diperhatikan juga permasalahan-permasalahan penghambat pembangunan ekonomi nasional yang datang bukan hanya dalam negeri saja, melainkan juga dari luar negeri. Salah satu contohnya adalah praktek curang dumping sebagaimana telah dibahas sebelumnya. Oleh karena itu, diperlukan aturan yang dapat mencegahnya agar pembangunan ekonomi nasional tidak terhambat. Dengan itulah pertumbuhan ekonomi yang berkelanjutkan dapat 
diwujudkan sesuai dengan apa yang ditetapkan dalam Rencana Pembangunan Jangka Panjang Nasional Indonesia.

\section{Pengesahan Perjanjian Internasional}

Membahas mengenai perdagangan internasional tentu tidak dapat terlepas dari landasannya, yaitu Perjanjian Internasional. Keberlakuan suatu perjanjian internasional di dalam suatu negara yang berdaulat memerlukan pengesahan berupa ratifikasi agar dapat berlaku di dalam negara tersebut. Tidak terkecuali di Indonesia yang memerlukan suatu landasan hukum agar perjanjian internasional yang diikutinya dapat disahkan ke dalam bentuk undang-undang atau ratifikasi. Selain itu juga harus ada landasan atas keterlibatannya dalam suatu perjanjian internasional. Kedua hal tersebut telah diatur dalam Pasal 11 ayat (1) dan (2) UUD 1945 sebagai berikut:

1. Presiden dengan persetujuan Dewan Perwakilan Rakyat menyatakan perang, membuat perdamaian dan perjanjian dengan negara lain.

2. Presiden dalam membuat perjanjian internasional lainnya yang menimbulkan akibat yang luas dan mendasar bagi kehidupan rakyat yang terkait dengan beban keuangan negara, dan/atau mengharuskan perubahan atau pembentukan undang-undang harus dengan persetujuan Dewan Perwakilan Rakyat.

Berdasarkan pasal tersebut kemudian dibuat pengaturan lebih lanjut mengenai pengesahan perjanjian internasional dalam Undang-Undang Nomor 24 Tahun 2000 tentang Perjanjian Internasional. Dengan demikian, telah jelas landasan yang dijadikan acuan untuk menentukan arah kebijakan dalam pengesahan suatu perjanjian internasional. Dalam konteks ini, pengesahan perjanjian internasional yang dimaksud adalah pengesahan terhadap Perjanjian Pembentukan Organisasi Perdagangan Dunia (WTO) beserta peraturan-peraturan yang menyertainya termasuk peraturan terhadap pencegahan praktek curang dumping dalam perdagangan internasional.

\section{Hukum Anti-Dumping}

Indonesia memerlukan instrumen hukum untuk menghadapi dumping. Hal pertama yang dilakukan Indonesia adalah dengan mengesahkan atau meratifikasi Perjanjian Pembentukan Organisasi Perdagangan Dunia (WTO) ke dalam Undang-Undang Nomor 7 Tahun 1994 tentang Pengesahan Agreement Establishing The World Trade Organization (Persetujuan Pembentukan Organisasi Perdagangan Dunia). Dengan meratifikasi perjanjian internasional tersebut maka Indonesia harus tunduk terhadap peraturan-peraturan yang ditetapkan dalam kerangka WTO termasuk kesepakatan-kesepakatan (agreements) yang ada di dalamnya. 
Salah satu agreement yang terdapat di dalamnya adalah Anti-Dumping Agreement atau yang bernama resmi Agreement on Implementation of Article VI of The General Agreement on Tariffs and Trade 1994. Indonesia kemudian melakukan tindak lanjut agar dapat mengimplementasikannya dengan mengeluarkan Undang-Undang Nomor 10 Tahun 1995 tentang Kepabeanan yang kemudian diperbaharui dalam Undang-Undang No. 17 Tahun 2006 tentang Perubahan Atas Undang-Undang Nomor 10 Tahun 1995 tentang Kepabeanan. Peraturan mengenai Anti-Dumping disisipkan di dalamnya pada bab IV bagian pertama. Dalam peraturan tersebut ditentukan apabila terbukti dumping, maka dikenakan Bea Masuk Anti Dumping (BMAD). Ketentuan mengenai Anti-Dumping tersebut kemudian diatur lebih lanjut pelaksanaannya, ke dalam Peraturan Pemerintah Nomor 34 Tahun 1996 tentang Bea Masuk Anti Dumping dan Bea Masuk Imbalan. Dengan adanya peraturan-peraturan tersebut menunjukkan komitmen Pemerintah Indonesia dalam melaksanakan perjanjian internasional di bidang perdagangan internasional yang telah disepakatinya. Selain itu berdasarkan peraturan-peraturan yang ada tersebut dapat dilihat juga arah kebijakan dari Pemerintah Indonesia terutama yang terkait dengan pencegahan praktik curang dumping.

\section{Penutup}

Arah kebijakan yang diberlakukan Pemerintah Indonesia dalam menghadapi praktek curang dumping oleh negara lain terhadap Indonesia dengan meratifikasi Perjanjian Pembentukan Organisasi Perdagangan Dunia (WTO) ke dalam Undang-Undang Nomor 7 Tahun 1994 tentang Pengesahan Agreement Establishing The World Trade Organization (Persetujuan Pembentukan Organisasi Perdagangan Dunia). Dengan ratifikasi tersebut Indonesia kemudian harus menyesuaikan kebijakannya dalam perdagangan internasional agar sesuai ketentuan WTO, termasuk menerapkan kebijakan anti-dumping sesuai dengan Anti-Dumping Agreement yang kemudian dituangkan dalam Undang-Undang Nomor 10 Tahun 1995 tentang Kepabeanan yang kemudian diperbaharui dalam Undang-Undang No. 17 Tahun 2006 tentang Perubahan Atas Undang-Undang Nomor 10 Tahun 1995 tentang Kepabeanan. Hal tersebut dilakukan sesuai dengan arah kebijakan perekonomian nasional yang menghendaki adanya demokrasi ekonomi yang mengandung ekonomi berkeadilan. Dengan adanya peraturan antidumping, perekonomian nasional dapat terlindungi khususnya bagi industri dalam negeri dan menghindarkan dari kerugian yang ditimbulkan praktek dumping tersebut sehingga pembangunan ekonomi nasional juga tetap dapat berjalan dengan baik. 
Berdasarkan pembahasan di atas dapat dilihat juga peran hukum dalam pembangunan ekonomi di Indonesia terkait dengan pencegahan praktek curang dumping. Hukum berperan sebagai alat untuk melaksanakan pembangunan ekonomi. Pembangunan ekonomi dapat terlaksana dengan baik tergantung pada peraturan yang dibentuk kemudian. Salah satu penghambat pembangunan ekonomi adalah adanya praktek curang dumping yang dilakukan oleh negara lain terhadap Indonesia. Oleh karena itu, hukum sebagai alat untuk melaksanakan pembangunan perlu mengatur pencegahan terhadap praktek dumping agar pembangunan ekonomi dapat tetap berjalan dengan baik. Hukum berperan sebagai alat untuk mencegah praktek dumping guna mendukung terlaksananya pembangunan ekonomi di Indonesia.

\section{Daftar Pustaka}

\section{Buku}

Ibrahim, Johnny, Teori dan Metodologi Penelitian Hukum Normatif, Bayumedia Publishing, Malang, 2008.

Sood, Muhammad, Hukum Perdagangan Internasional, Cetakan Kedua, Rajawali Pers, Jakarta, 2012.

Syahyu, Yulianto, Hukum Anti Dumping di Indonesia: Analisis dan Panduan Praktis, Cetakan Pertama, Ghalia Indonesia, Jakarta, 2004.

van den Bossche, Peter, Daniar Natakusumah dan Joseph Wira Koesnaidi., Pengantar Hukum WTO (World Trade Organization), Cetakan Pertama, Yayasan Obor Indonesia, Jakarta, 2010.

\section{Jurnal}

M. Ya'kub Aiyub Kadir, "The World Trade Organization (WTO) Free Trade within Fair Trade Challenges", Mimbar Hukum, Vol. 26, No. 1, Februari 2014.

Mardalena Hanifah, "Arah Kebijakan Hukum Politik Ekonomi", Jurnal Ilmu Hukum, Vol. 3, No. 1, (Tanpa Tahun).

Muh. Risnain, "Politik Hukum Perlindungan Industri dalam Negeri Indonesia dalam Menghadapi Perdagangan Bebas", Fiat Justisia Jurnal Ilmu Hukum, Vol. 5, No. 3, September - Desember 2011.

\section{Peraturan Perundang-undangan}

Undang-Undang Dasar Negara Republik Indonesia Tahun 1945.

Undang-Undang Nomor 17 Tahun 2007 tentang Rencana Pembangunan Jangka Panjang Nasional Tahun 2005 - 2025.

Undang-Undang Nomor 24 Tahun 2000 tentang Perjanjian Internasional. 